\title{
A Preliminary Study on the Variation of Zooplankton Diversity, Abundance and Density in a Selected Branch of Diyawanna Oya Canal System
}

\author{
L. G. Ruwini Yasadari Perera* \\ Department of Zoology, The Open University of Sri Lanka
}

\begin{abstract}
Zooplankton make the secondary level in aquatic ecosystems and provide a ready source of food for secondary consumers. Hence any fluctuation in their population will directly affect the food webs, and eventually the whole ecological system. This study was carried out along a main branch of Diyawanna Oya, during the period of February to July, 2003. The objectives of the study were to find out the variation in diversity, abundance and density of zooplankton present in a selected branch of Diyawanna Oya and their correlation with some environmental parameters. Zooplankton $\&$ water samples were collected monthly from six stations representing both edges and the middle of the canal. During the study, 39 species of rotifers, 9 species of cladocerans, 6 species of copepods, 5 species of ostracods, some larval stages of malacostracans, 2 species of large protozoans and one Tardigrade species were recorded. There was a significant monthly variation in the average density of zooplankton. It was positively correlated with the flow rate $(\mathrm{r}=0.81)$, depth $(\mathrm{r}=$ $0.47)$ and temperature $(r=0.58)$ of water. And there was a significant variation in density and abundance among six sampling stations. Density values of stations were positively correlated with DO level $(r=0.72)$ while it was negatively correlated with total alkalinity $(\mathrm{r}=-0.78)$, total hardness $(\mathrm{r}=-0.67)$ and conductivity $(\mathrm{r}=$ -0.6). The highest average density of zooplankton was recorded from Kotte whereas the least was from Torrington. Additionally, the possibility of ousing Lacane sp., Philodina sp. and Moina micrura taxa as indicators was also noted.
\end{abstract}

Keywords: Zooplankton, Diyawanna Oya, environmental parameters, correlation, indicators

* Correspondence should be addressed to Ms. L. G. Ruwini Yasadari Perera

(Email : ousl.ruvini@gmail.com) 


\section{Introduction}

Diyawanna Oya canal system with its surrounding environment is one of the precious assets which exist in the Colombo metropolitan of Sri Lanka. The system has added economical, historical, environmental and recreational value to the capital of Sri Lanka. In order to maintain the good health of this water body, it is important to monitor the status of water quality by measuring any changes in abiotic or biotic factors regularly. Therefore several local authorities plus some government agencies such as Land Reclamation and Development Cooperation (SLLRC) and Urban Development Authority (UDA) are in-charge of its proper maintenance and development. Recent studies have proven that some Zooplankton species and their dimensions can be used as indicators in monitoring water quality (Haberman and Haldna, 2014). Thus, the current study can be considered as a preliminary study that mainly focusses on Zooplankton diversity and their distribution in Diyawanna Oya Canal system. It can also be used as a baseline survey on the status of the canal system particularly on zooplankton, prior to the initiation of development activities around the area.

Sampling process of this study was carried out in 2003. Soon after, due to the speedy development taken place in Sri Jayawardenapura, Kotte urban area, most of the natural aquatic habitats were disturbed, restored, restructured or altered. Though zooplankton have short life spans and can regenerate within a short period of time, it would be worth keeping track on pre and after records on environmental status of the canal system to monitor the extent to which development has affected the environment.

Zooplankton are microscopic organisms, which drift or float freely in any water column. They mostly live in the pelagic zone of oceans, seas, or in freshwater bodies. Freshwater zooplankton play a major role as primary consumers in lower trophic levels of most aquatic food chains and food webs. They are also involved in nutrient cycling and affect the density of phytoplankton in water bodies. Zooplankton are also one of the most important nutrient rich food sources for fish fry and for some adult fishes that live in aquatic systems (Battish,1992). The main taxonomic groups of zooplankton in fresh water bodies are Crustacea (Cladocera, Copepoda, Ostracoda), Rotifera, Gastrotrichs and Protozoa.

According to Fernando (1974), Sri Lanka has no natural lakes, yet over 10,000 'Lakes' have been constructed for irrigation of rice fields, 
water storage, for drinking and for the generation of hydroelectric power. They have been colonized by zooplankton via the rivers and have a relatively rich fauna except for typical lake species. Zooplankton in these man-made lakes are poor in species diversity and they are also poor in littoral and benthic animals. According to Fernando (1974), zooplankton community in low country shallow lakes is diverse in species composition. However, in the up country reservoirs, the zooplankton species are few that results in a very low fish production in these lakes.

Most common taxa of zooplankton in Sri Lanka are Rotifera, Cladocera, Copepoda and Ostracoda. Around 140 Rotifera species belonging to 42 genera have been recorded from Sri Lanka (Rajapaksa \& Fernando, 1984). Species of both limnetic and littoral forms were among them. The planktonic Rotifers of Sri Lanka are mainly represented by the members of 7 families known as Brachionidae, Asplanchnidae, Synchaetidae, Hexarthridae, Conochilide, Filinidae and Collothecidae. Their species diversity is lower in the limnetic habitats than in the littoral (Rajapaksa and Fernando, 1984).

The composition of the Cladocera in Sri Lanka is typically tropical with few Daphnia and Ceriodaphnia species, which are the dominant species in the temperate zone (Fernando, 1980a). About 68 species of Cladocera belonging to 7 families (Sididae, Daphnidae, Bosminidae, Monidae, Macrothricidae, Chydoridae and Leptodoridae) have been recorded from Sri Lanka (Rajapaksa and Fernando, 1984).

Twenty-seven species of Copepods belonging to 3 groups are recorded from the freshwater habitats of Sri Lanka. They compose 13 species of Cyclopoids, 11 species of Calanoids and 3 species of Harpacticoids (Rajapaksa and Fernando, 1984). Two species of Gastrotricha were recorded by Fernando \& Mendis in 1962.

A few species of Osrtracoda occur as zooplankton. Most of the recorded species in Sri Lanka are benthic, some occur among the aquatic vegetation (Rajapaksa and Fernando, 1984).

\section{Description of the Study Area}

Diyawanna Oya is a man-made canal system which is located in the left bank of the lower valley of Kelani River in the Colombo district, Western province of Sri Lanka, within the ranges of latitudes 652 ' 55” - 6 55' 45” N and longitudes 79 52' 35” - 79 55' 15” E. 
The canal system functions as the main drainage system of Colombo city. Since its elevation is closer to the sea level and flow rate depends on the storm water, water body becomes stagnant or slow moving during the dry period. As a result, industrial and domestic waste disposed to the water body does not flush away easily. Eventually it generates many health hazards to the public who live in the surrounding area. The major catchment areas of this system are the low-lying marshlands known as Kolonnawa marsh, Heen-ela marsh and Kotte marsh. These are also important as major flood detention zones in the city of Colombo (Wetland Site Report, 1995). Total land area that covers those marshy areas was around 400 ha. Out of them Kolonnawa is the largest marsh (214.3 ha) while Heenela is the smallest ( 87.7 ha). Figure 1 illustrates the study area, which includes a main canal (Diyawanna-Wellawatta canal), 6 sampling stations, and two marshes namely Kotte (KM) and Heen marsh (HM).

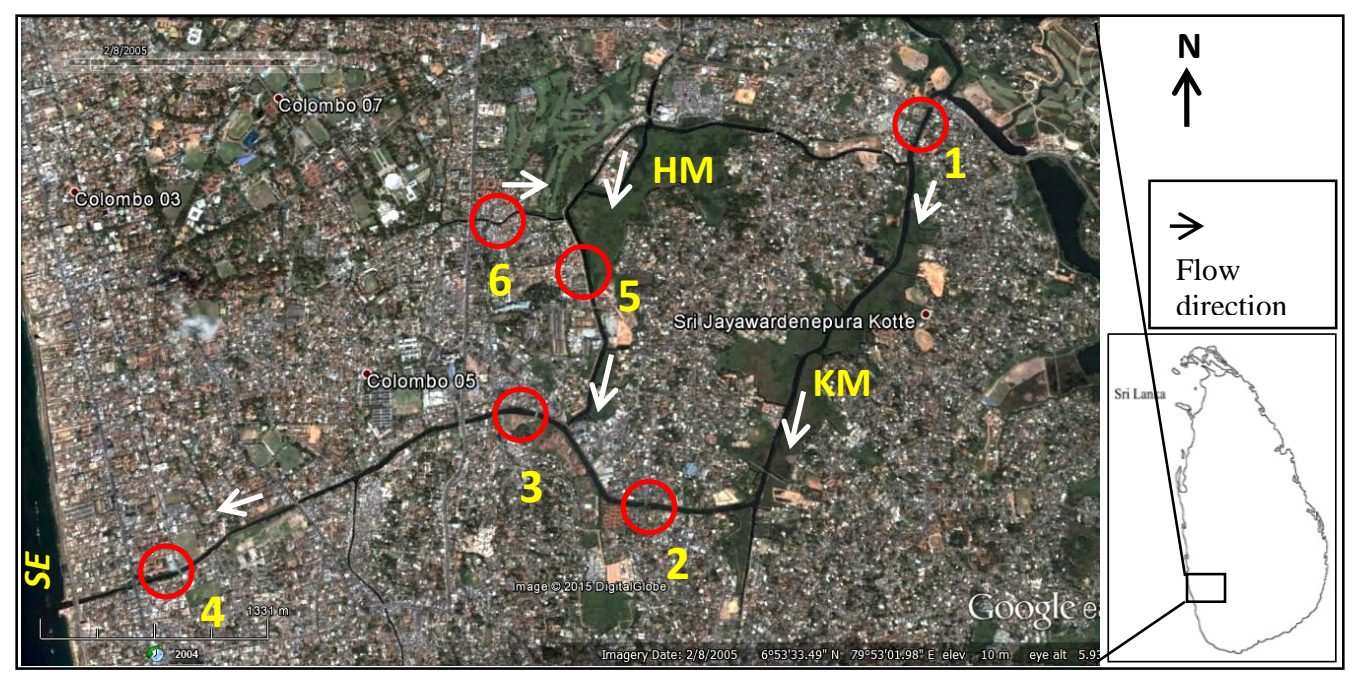

Figure 1. Site map of the study area : Diyawanna Oya Canal system and six sampling stations. (1. Kotte, 2. Nawala, 3. OUSL, 4. Wellawatta, 5. Kirimandala Mw., 6. Torrington, KM Kotte Marsh, HM - Heen Marsh)

The depth of these canals reduces or fluctuates due to the heavy soil erosion and sedimentation of silt during the rainy season. Therefore to control bank erosion, most of the banks are covered with stone 
barriers \& wire meshes known as 'gabions'. The average depth of the canals is about 1.5 meters. Canal system often clogs with floating weeds \& dumps (polythene, plastics \& domestic wastes). It has been found that $43.5 \%$ of the families in the study area dump their household garbage into the marsh (Wetland Site Report, 1995).

The main objectives of the study were to find out the variation of zooplankton species diversity, density and abundance along a main branch of Diyawanna Oya. Another objective is to find out if there is any correlation between density variation and some environmental parameters recorded during the study.

\section{Materials and Methods}

\section{Sampling Site:}

Six sampling stations were selected, which were different from one another in respect of human influences and environmental factors. Selection procedure was mainly focused on the presence of marshes, industries and human settlements. Kotte and Nawala stations were the least populated areas, where as Torrington consisted of large numbers of settlements. OUSL station was heavily affected by industrial wastes while Right bank of Kirimandala Mawatha station was affected by Nitrogen rich discharges, released by some food factories. Wellawatta station was located in an urbanized area, which was also affected by seawater intrusion. The easy access to the sampling point was also considered when selecting these sampling stations.

\section{Sampling Method:}

Zooplankton were collected from all six stations once a month, during the period of February to July 2003 using a conical plankton tow net with $100 \mu \mathrm{m}$ mesh size and $0.30 \mathrm{~m}$ mouth diameter. It was towed horizontally between surface and $0.5 \mathrm{~m}$ depth for about 20 meters distance along the canal, both in two banks and from the middle of the canal using a non-mechanized boat. The volume of water filtered through the net was approximately $1.413 \mathrm{~m}^{3}(1413$ Litters). At the same time some environmental parameters such as temperature, flow rate and water level were measured on the spot. Additionally, water samples were collected for further analysis of DO, $\mathrm{pH}$, Conductivity, Alkalinity and $\mathrm{Cl}^{-}$concentration. Preserved plankton samples were analyzed at the laboratory by using the light microscope. Identification of zooplankton was done using keys and some illustrated guides authored by Fernando \& Mendis (1962), 
Fernando $(1963,1969 \& 1974)$, Chengalath \& Fernando $(1974,1974)$, Fernando (1984), Neale (1984), Battish (1992), Edmondson (1959), Dole-Olivier et al., (2000), Ricci \& Balsamo(2000) and Barnes (1998).

\section{Results}

\section{Species Diversity of Zooplankton in Diyawanna Oya}

Among zooplankton, thirty-nine (39) species of rotifers, nine (9) species of cladocerans, six (6) species of copepods, five (5) species of ostracods, some larval stages of malacostracans, one (1) species of Branchiopods, two (2) large protozoans and one (1) tardigrade species were recorded. Among rotifers Brachionus falcatus, Lecane bulla and Philodina sp. were the most abundant. Ceriodaphnia cornuta, Diaphanasoma excisum and Moina micrura were the most abundant cladoceran species.

The checklist of zooplankton recorded during the study has been given in Table 1 .

\section{Variation of Zooplankton Diversity within Six Sampling Stations}

It was revealed that Nawala station, which is nourished with water coming from Kotte marsh, had the highest zooplankton species richness while Torrington which was heavily influenced by human activities had shown the lowest. The graph below (Fig. 2) illustrates the pattern of variation of zooplankton diversity (species richness) among six sampling stations. Further to Shanon-Wiener Diversity Index, Kotte station has scored the highest value of 3.36 where as Nawala, OUSL, Wellawatta, Kirimandala Mw. and Torrington stations area $3.27,2.98,2.79,2.85$ and 0.82 respectively. 
Table 1. Checklist of zooplankton taxa \& their total number of occurrence during the study ( $\mathrm{N}=$ Number of Occurrence)

\begin{tabular}{|c|c|c|c|}
\hline Taxonomy & $\mathbf{N}$ & Taxonomy & $\mathbf{N}$ \\
\hline $\begin{array}{l}\text { Phylum Rotifera } \\
\text { Order Ploimida }\end{array}$ & & $\begin{array}{l}\text { Phylum Arthropoda } \\
\text { Class Crustacea } \\
\text { Order Cladocera }\end{array}$ & \\
\hline Brachionus angularis & 5 & Diaphanasoma excisum & 36 \\
\hline Brachionus calyciflorus & 32 & Ceriodaphnia cornuta & 49 \\
\hline Brachionus caudatus & 16 & Monia micrura & 43 \\
\hline Brachionus donneri & 12 & Bosminopsis dietersi & 34 \\
\hline Brachionus falcatus & 44 & Oxyurella sinhalensis & 3 \\
\hline Brachionus forficula & 4 & Psedochydorus globosus & 1 \\
\hline Brachionus patulus & 13 & Macrothrix triserialis & 18 \\
\hline B. quadridentatus & 9 & Euryalona orientalis & 14 \\
\hline Platyias quadricornis & 11 & Ladigia acanthocercoides & 4 \\
\hline Keratella tropica & 14 & Sub class Copepoda & \\
\hline Lecane bulla & 44 & Order Cyclopoida & \\
\hline Lecane quadridentata & 4 & *Mesocyclops sp. & 66 \\
\hline Lecane ungulata & 3 & *Thermocyclops crassus & 51 \\
\hline Lecane sp1 & 10 & nauplii stage 1 & 86 \\
\hline Lecane sp2 & 1 & nauplii stage 2 & 61 \\
\hline Lecane sp3 & 5 & Order Calanoida & \\
\hline Lecane sp4 & 5 & Phyllodiaptomus sp. & 50 \\
\hline Lecane sp5 & 2 & Eudiaptomus sp. & 41 \\
\hline Lecane sp6 & 32 & nauplii stage 1 & 62 \\
\hline Philodina sp. & 68 & nauplii stage 2 & 37 \\
\hline Asplanchna brightwelli & 18 & Order Herpactocoida & \\
\hline Euchlanis dilatata & 28 & sp. 1 & 2 \\
\hline Trichocera cylindrica & 2 & Class Ostracoda & \\
\hline Trichocera chattoni & 14 & Order Podocopida & \\
\hline Lepadella patella & 1 & Super Family :Cypridoidae & \\
\hline Scaridium longicaudum & 1 & $s p .1$ & \\
\hline Testudinella patina & 19 & sp. 2 & 1 \\
\hline Filinia $s p .1$ & 3 & sp.3 & 17 \\
\hline Filinia sp.2 & 3 & Class Malacostraca & 1 \\
\hline Macrochaetus collinsi & 1 & crab nauplii 1 & \\
\hline Macrochaetus sericus & 2 & crab nauplii 2 & 1 \\
\hline Trichotria tetractis & 1 & crab nauplii 3 & 4 \\
\hline Sinantherina spinosa & 7 & Insecta & 4 \\
\hline Sinantherina semibullata & 33 & Odonata nymphs & \\
\hline Cephalodella giba & 14 & Protozoa & 9 \\
\hline Hexarthra mira & 30 & Arcella sp. & \\
\hline \multirow[t]{3}{*}{ Mytillina $s p$} & 1 & Centropyxis sp. & 22 \\
\hline & & phylum Tardigrada & 10 \\
\hline & & $s p .1$ & 8 \\
\hline
\end{tabular}




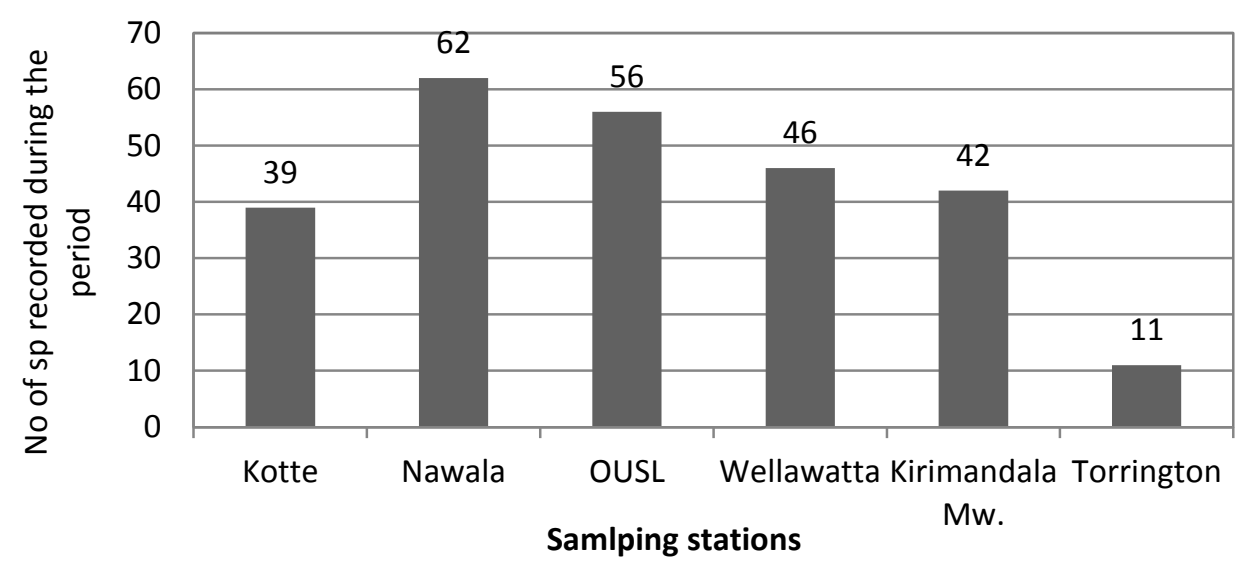

Figure 2. Variation of zooplankton diversity (species richness) among six sampling stations

\section{Relative Abundance of Some Major Taxonomic Groups of Zooplankton}

Figure 3 shows the variation of relative abundance (\%) of 10 frequently recorded zooplankton taxa in six sampling stations during the study period. The abundance values (no of individuals per cubic meter) of those taxa for each and every station have been given in the graph. According to the graph, except for Torrington, Copepod adult and nauplii have been the most abundant taxa (over $40 \%$ ) in almost all stations. For Torrington it was Moina micrura, which is a cladoceran species and showed the relative abundance around 50\%. Though Wellawata showed relative abundance more than $40 \%$ as a total figure for copepod adults and nauplii, the most dominant taxa for the station was philodina sp which is a Rotifer species.

\section{Variation of Zooplankton Density}

There was a significant monthly and spatial (station wise) variation of zooplankton density in Diyawanna Oya. According to Figure 4 the highest zooplankton density was recorded in March, 2003 whereas the lowest was in July, 2003. When considering the average density variation of the six stations, Kotte station has recorded the highest zooplankton density while Torrington has shown the lowest (see Figure 5). 


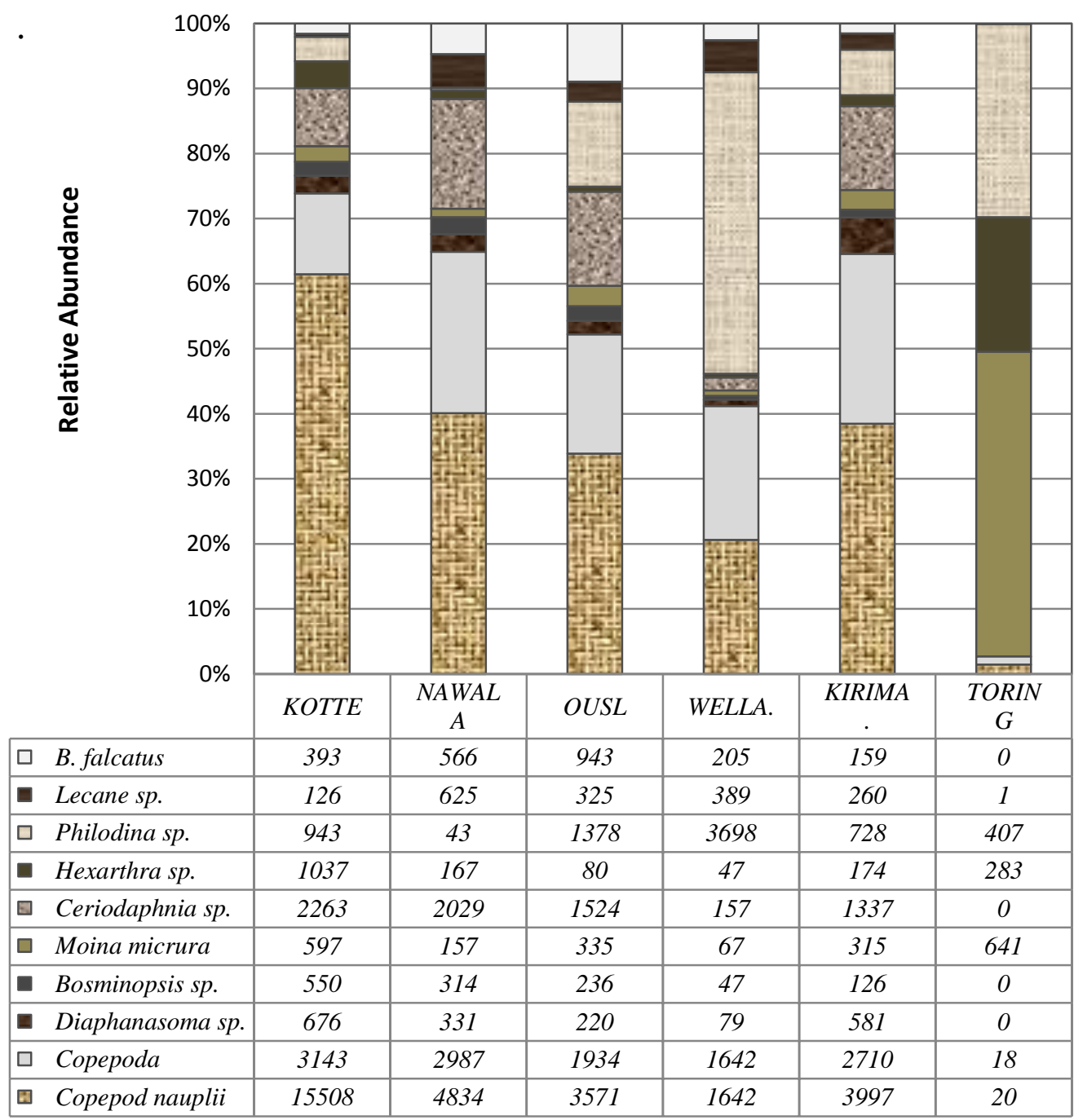

Sampling stations and abundance values (no. of ind $/ \mathrm{m}^{3}$ )

Figure 3. Variation of relative abundance of ten frequently occurred zooplankton taxa in six sampling stations and their abundance values (individuals per cubic meter). 


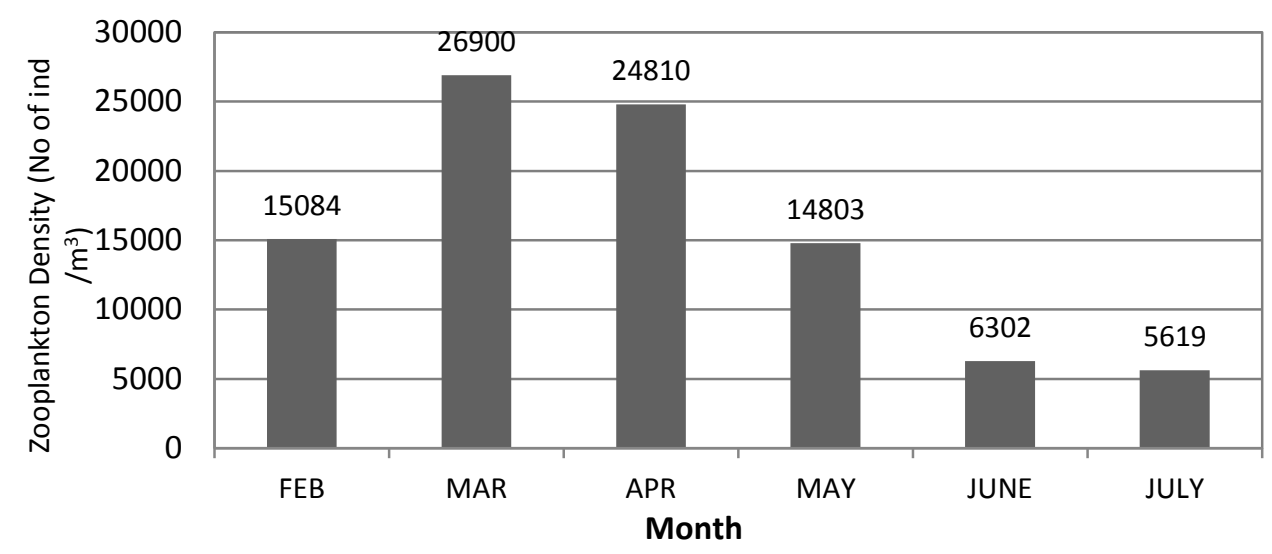

Figure 4. Monthly variation of zooplankton density in Diyawanna Oya (Feb-July 2003)

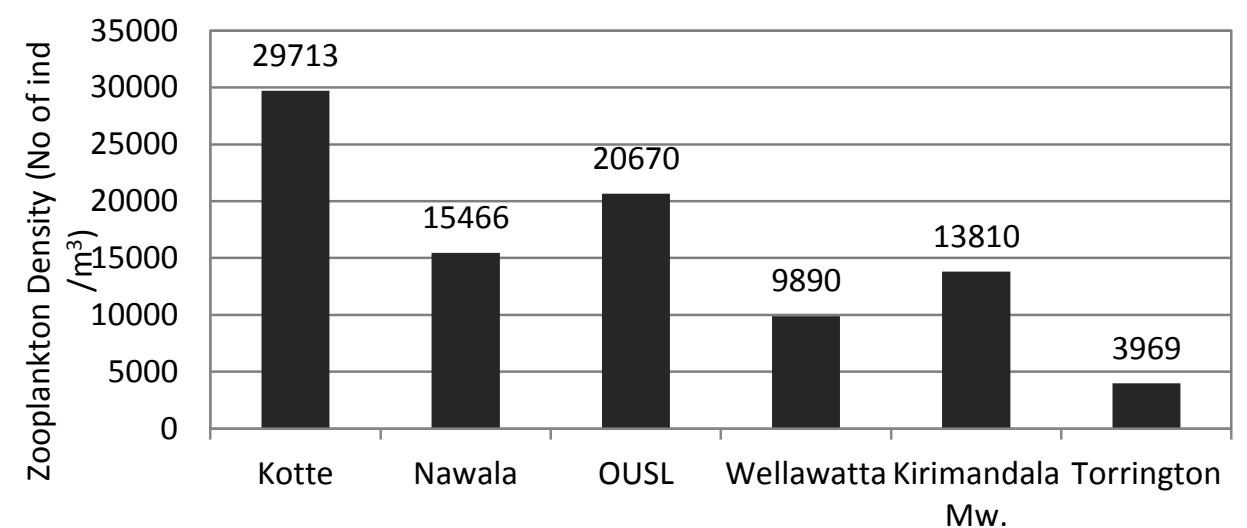

Sampling station

Mw.

Figure 5. Variation of zooplankton density among six sampling stations during the study period

\section{Correlation Between Monthly Variations of Zooplankton Density and Some Environmental Parameters}

Environmental parameter readings obtained from six stations were averaged and tabulated (Table 2) on monthly basis. Highest values recorded for each parameter are highlighted in the table. The highest rainfall was recorded in the month of May. Highest air and water temperature values were recorded in April. Chloride ion concentration was significantly high in both February and July. Dissolved Oxygen content of water has shown a peak value in March and secondly in June. 
Monthly variation of overall zooplankton density of Diyawanna Oya was positively correlated with flow rate $(\mathrm{r}=0.81)$, water temperature $(\mathrm{r}=0.58)$, depth $(\mathrm{r}=0.47)$ and dissolved oxygen content $(0.26)$. Graphs in figure 6 have illustrated the pattern of monthly variation of zooplankton density and above mentioned environmental parameters together with their correlation values (r).

Table 2. Monthly variation of some environmental parameters of the study area, Diyawanna Oya (overall view) during the period of Feb July, 2003.

\begin{tabular}{|c|c|c|c|c|c|c|}
\hline Parameter & Feb & Mar & Apr & May & Jun & Jul \\
\hline Rain fall (mm) & 89.3 & 164 & 95.9 & 284.8 & 181.6 & 185.7 \\
\hline Air temp $\left(\mathrm{C}^{\circ}\right)$ & 31.4 & 32.33 & 33.2 & 33 & 32.5 & 31.8 \\
\hline Water temp $\left(\mathrm{C}^{\circ}\right)$ & 30.75 & 31.75 & 31.88 & 31.6 & 31.25 & 31 \\
\hline Flow rate $\left(\mathrm{ms}^{-1}\right)$ & 0.1116 & 0.1496 & 0.1573 & 0.1046 & 0.0530 & 0.0762 \\
\hline Water level (m) & 0.23 & 0.35 & 0.32 & 0.29 & 0.37 & 0.37 \\
\hline Average depth (m) & 0.773 & 0.779 & 0.733 & 0.755 & 0.742 & 0.700 \\
\hline $\mathrm{pH}$ value & 6.57 & 7.35 & 6.41 & 6.18 & 6.65 & 6.58 \\
\hline Tot. Hardness (m.mol. $\mathrm{l}^{-1}$ ) & 0.00031 & 0.00026 & 0.00027 & 0.00028 & 0.00028 & 0.00029 \\
\hline Tot. Alkalinity (m.mol. $\mathrm{l}^{-1}$ ) & 0.00036 & 0.00028 & 0.00022 & 0.00024 & 0.00019 & 0.00023 \\
\hline $\mathrm{Cl}^{-}$concentration $\left(\mathrm{mgl}^{-1}\right)$ & 112.65 & 45.26 & 72.42 & 50.04 & 64.12 & 111.90 \\
\hline DO level $\left(\mathrm{mgdm}^{-3}\right)$ & 3.12 & 3.55 & 2.38 & 1.45 & 3.03 & 2.05 \\
\hline
\end{tabular}

Table 3. Average values of some environmental parameters recorded from six sampling stations of Diyawanna Oya (Feb - July, 2003).

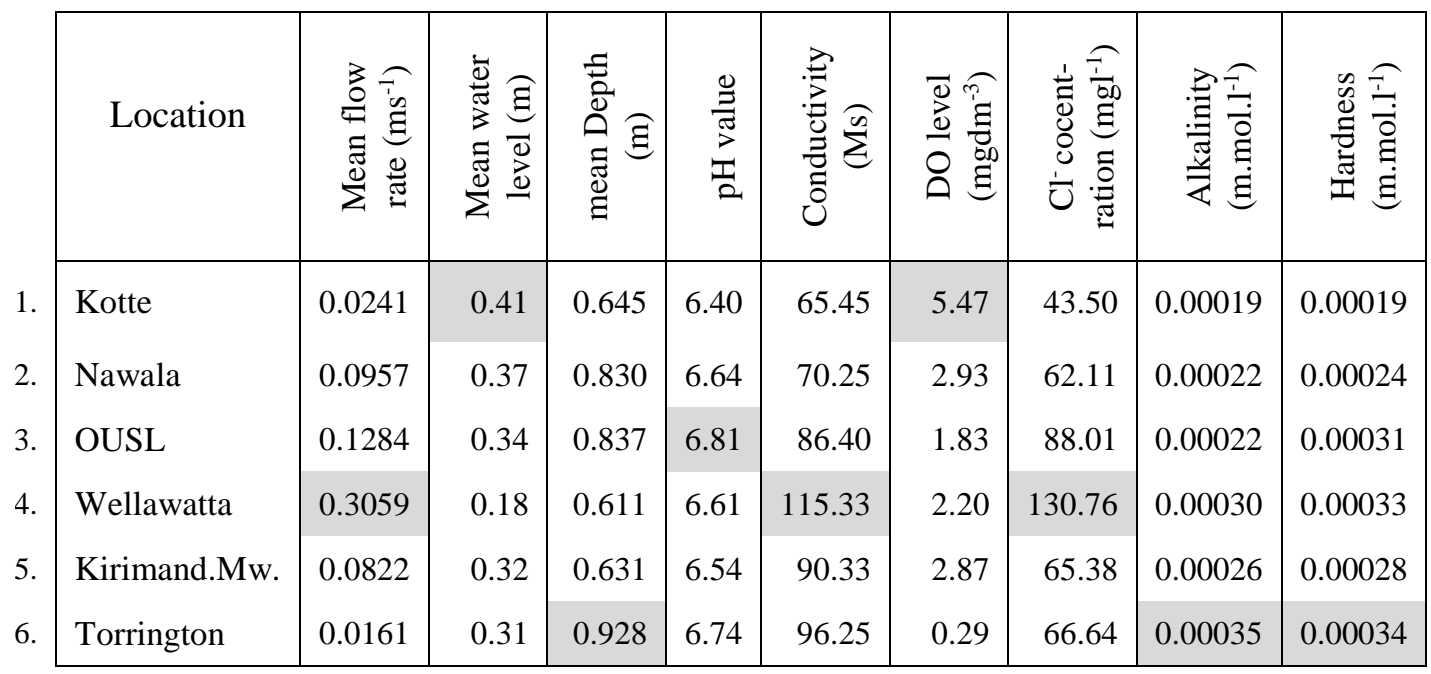



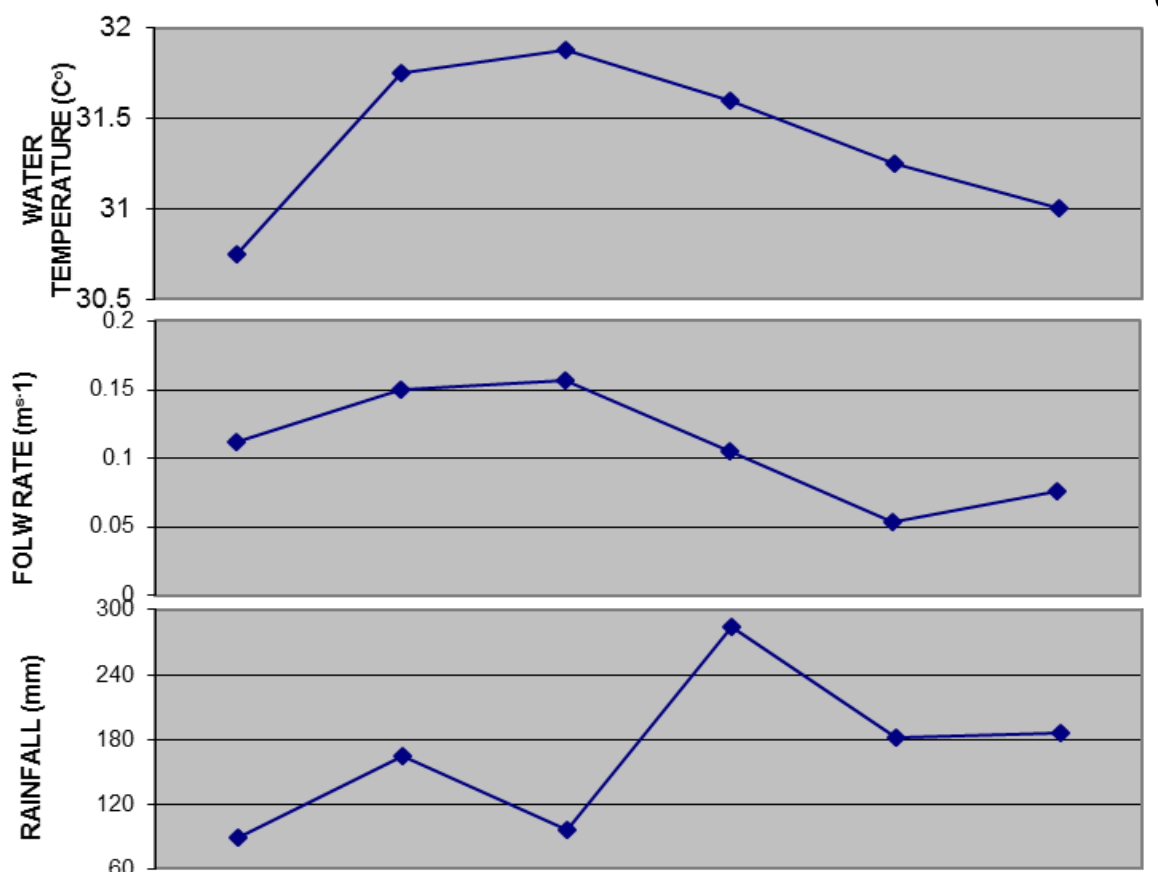

$r=0.58$

S

$r=0.81$

NS

$r=-0.28$

NS

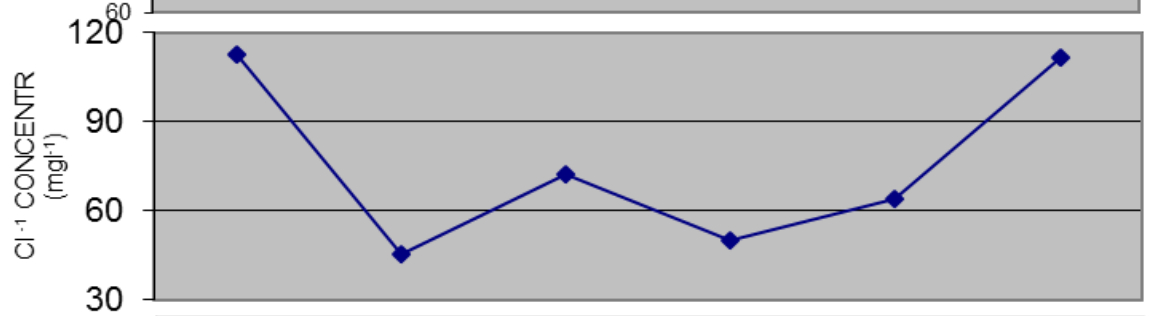

$r=-0.39$

S

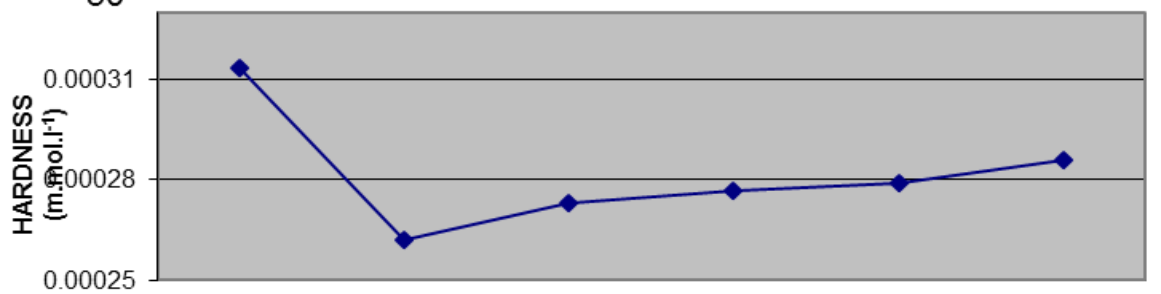

$r=0.35$

NS

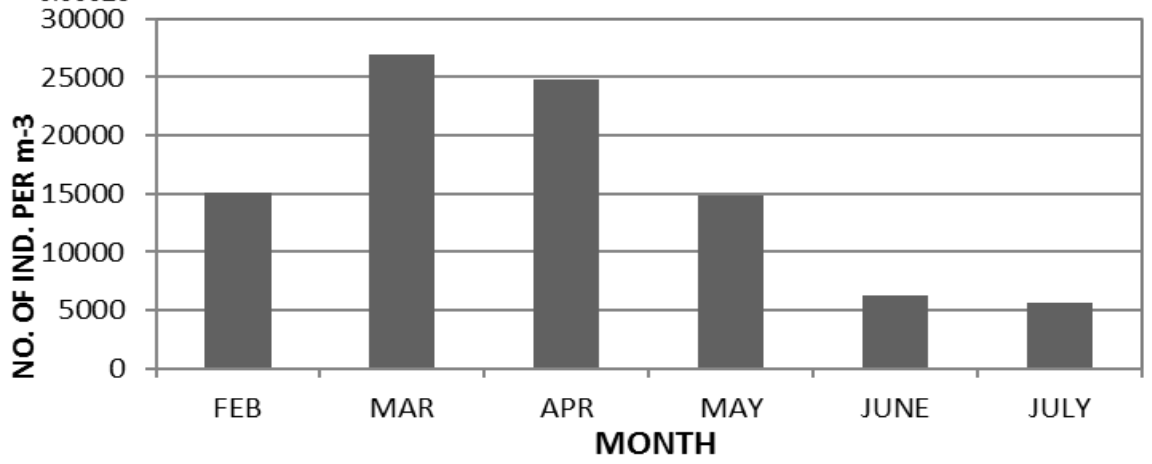

Figure 6. Monthly variation of zooplankton density (No. of ind. $/ \mathrm{m}^{3}$ ) and its correlation with some environmental parameters recorded from the study area, Diyawanna Oya 


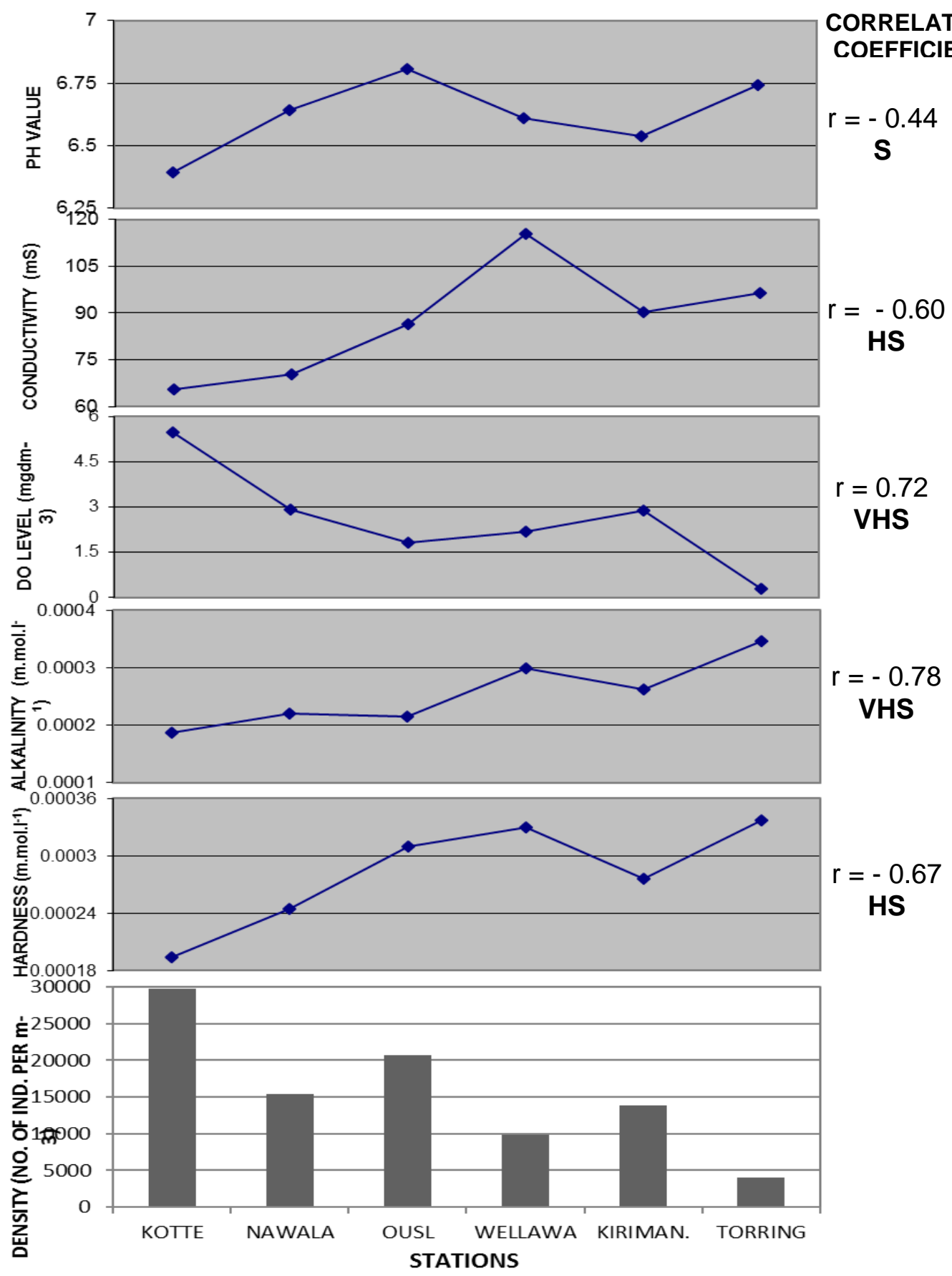

Figure 7. Variation of average zooplankton density (No. of ind. $/ \mathrm{m}^{3}$ ) in six sampling stations and its correlation ( $\mathrm{r}$ value) with some environmental parameters recorded from the study area. 
Table 4 has given the statistically analysed correlation coefficient values $(\mathrm{r})$ and their level of significance for each and every relationship. Flow rate has shown a Very High Significant Positive Correlation (VHS) with the density variation while water temperature and depth have shown a Significant Correlation (S). Though Dissolved Oxygen Content has showed a positive correlation, it was not a significant relationship.

Table 4. Correlation coefficient (r) between density and some environmental parameters. [VHS - Very High Significant Correlation $(r>0.70)$, HS - High Significant Correlation $(r>0.6 /<0.74), \mathrm{S}-$ Significant Correlation $(r>0.35 /<0.59)$, NS - No Significant Correlation $(\mathrm{r}<0.35)]$

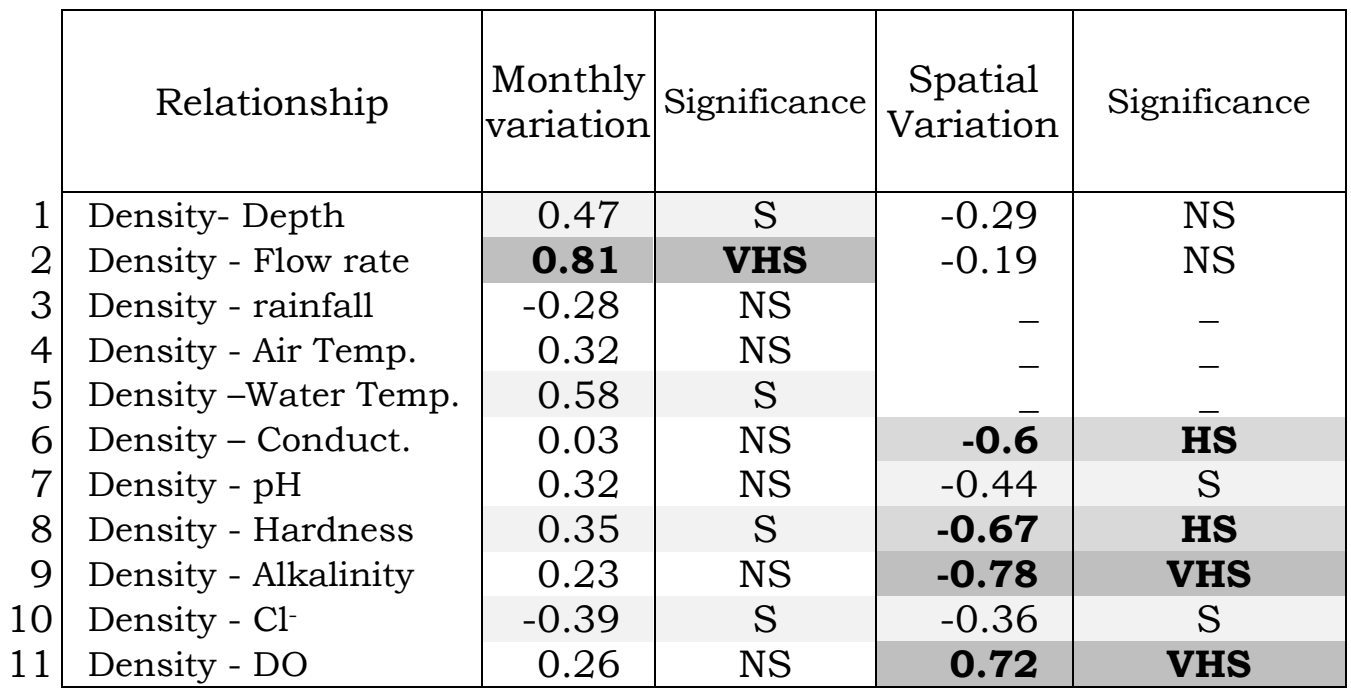

\section{Correlation Between Zooplankton Density Variation in Six Sampling Stations and Environmental Parameters}

Environmental parameter values obtained from six sampling stations during the study were averaged and given in Table 3. As per values given in the table flow rate, conductivity and Chloride ion concentration values recorded in Wellawatta station were considerably higher than all other stations. A remarkable average Dissolved Oxygen value (5.47 $\mathrm{mgdm}^{-3}$ ) was reported from Kotte station.

When considering their correlation with zooplankton density variation in six stations, it has shown a Very High Significant (VHS) positive correlation with dissolved oxygen $(r=0.72)$, Very High Significant (VHS) negative correlation with total alkalinity $(r=-0.78)$, and High Significant (HS) negative correlation with both total 
hardness $(\mathrm{r}=-0.67)$ and conductivity $(\mathrm{r}=-0.6)$. Graphs in fig. 7 illustrate clearly the pattern of zooplankton density variation in six sampling stations with some environmental parameter values.

\section{Discussion}

Overall zooplankton community in Diyawanna Oya study area was composed of Rotifers (39 species) that represented the highest diversity, Cladocerans (9), Copepods (6), Ostracods (5), Protozoans (2) and some larval forms and minor groups (Tardigrata). Similar results were obtained in Prakrama Samudra by Fernando \& Rajapaksa in 1983. They have recorded 32 species of Rotifers, 7 species of Cladocerans, 6 species of Copepods and 4 species of Protozoans etc. Correspondingly in Bolgoda Lake, Wignarajah \& Amarasiriwardana (1983) have found that the highest number of species belonged to Phylum Rotifera, and others ( Copepoda, Cladocera and Ostracoda) were with lower numbers. From a study conducted in Vortsjarv Lake, Central Estonia in the growing season, has identified 54 metazooplankton species that include with 29 Rotifers, 17 Cladocerans, and 8 copepods have been identified (Haberman \& Haldna, 2014) . Another investigation on limnological features and zooplankton assemblage study performed in Funil Reservoir, Rio de Jeneiro, Brazil by Branco et al. (2002) recorded parallel results for zooplankton composition as in 21 Rotifer species, 6 Cladocerans, 3 Copepods and some testate amoeba varieties.

From a recent study carried out by Wickramasinghe, et al. (2012) in Kotte and Kolonnawa wetland, has revealed a total of 12 taxa of zooplankton that composed of 8 Rotifers, 3 Copepods and 1 Cladoceran species. Though their abundance is aligned with this study, their species richness is poor than what we have recorded in 2003. Causes behind above contrast would be due to the drastic changes which happened in wetland land use pattern and the canal system with the development activities commenced in the area by 2005 or may be due the method used for zooplankton sampling. As in this study approximately 1413 Litters of freshwater were filtered through the plankton net to collect zooplankton while it was only 10 Litters by Wickramasinghe, et al. (2012). This hypothesis is further assisted by the study carried out in Lakes of the Northern Coast of Rio Grande do Sul state, Brazil on zooplankton and water quality by Pedrozo \& Rocha (2005), where they have filtered 300 litters of water using a suction pump and plankton nets. From that study, 62 taxa were identified, which consisted of by 40 Rotifera taxa, 15 Cladocera 
taxa and 7 Copepoda taxa, showing comparatively a high species richness of zooplankton.

Additionally, some studies were carried out in Beira Lake, which were also a part of the Colombo canal system but not directly connected with Diyawanna Oya by several other researchers. It is noteworthy that zooplankton diversity in Beira Lake was relatively lesser than common inland freshwater habitats. During the study conducted by Kamaladasa \& Jayatunga (2007) only a total of 10 zooplankton species were found from both South and East Beira Lakes. Among them there were 6 Rotifers, 3 Cladocerans and 1 Copepod species. According to the records of hydro biological investigations done by Costa \& De Silva (1969) Brachionus sp., Keratella sp., Diaphanosoma sp., Diaptomus sp., Cyclops sp., and crustacean nauplii were the most notable of the Zooplankton, with copepod cyclopoidea.

In the present study, there was a remarkable variation of species diversity within the sampling stations. Higher diversity index values were recorded from Kotte and Nawala, which were influenced by Kotte and Heen marshes. Some species like Hexartha sp., Diaphanasoma sp. and Ceriodaphnia sp. were also commonly found from these stations. However, the most common taxa in Kotte were Copepod adults and nauplii throughout the study period. On the other hand, Torrington which was the least diverse station and heavily affected by domestic pollutants, was the station where Moina micrura and Philodina sp were the most abundant species recorded. Moina micrura is considered which is of the "tolerant" or "benefited" by the organic contamination in the system (Pedrozo \& Rocha, 2005). Therefore, high abundance of Moina micrura can be an indicator of high level of organic pollution.

Overall density of zooplankton had fluctuated outstandingly throughout the study period. Higher values were obtained just before the commencement of the rainy season. Similar results have been obtained for Rotifer species by Costa \& De Silva (1978) in Beira Lake. The maximum number of Rotifers was recorded in the drier months (June and July) or before the monsoon period. According to the observation of Wignarajah \& Amarasiriwardena (1983) in Bolgoda Lake, only the populations of nauplii showed peaks with the monsoonal periods, while the rest of the zooplankton population showed higher fluctuations with peaks during the inter-monsoonal periods. The reason behind this is perhaps the ability of Copepods for movement against water flow with their body size and biomass which is comparatively higher and much favourable to withstand 
heavy storm water movements which take place in monsoon than other zooplankton groups.

Variation of zooplankton density has shown a significant negative correlation with Chloride ion concentration $\left(\mathrm{Cl}^{-}\right)$level during the study period. This may be due to the inflow of saline water through canals upwardly during the high tidal season probably by June onwards. Wallawatta, OUSL and Nawala were the stations that are directly subjected to this situation. In the months of June and July, density and abundance of zooplankton in these stations had fluctuated. Interestingly the abundance of Lacane sp. has increased during these months. Hence, there is opportunity of considering Lacane sp. as an indicator of high $\mathrm{Cl}$ ion concentration or saline water intrusion.

Monthly variation of zooplankton density had positively correlated with the Flow rate, DO level and water temperature during the six months study period. Mean flow rate, DO values and water temperature were higher in March and April while they were lower in later months. As noted by Schöll \& Kiss (2008) the ability of some zooplankton taxa (rotifers) to reproduce in waters with high flow velocities (above $0.4 \mathrm{~m} / \mathrm{s}$ ) is very low, or indeed nil. Lower flow rates in later months may be a result of stagnation of water by obstructing freshwater runoff to the sea and rising of sea water level in the high tidal season. This could have also caused low DO content in water due to lessening of water movements. Temperature was declined due to the variation of weather in the monsoon period, which also has shown some significant positive correlation with density variation in six month. Branco (2002) revealed that some Rotifer taxa such as Brachionus calyciflorus and Euchlanis dilatata were associated with increasing of water temperature. As per Matsumura-Tundisi et al.(1990) cited by Pedrozo \& Rocha (2005) Rotifers are opportunistic organisms whose densities change with temperature in a short time, some of them can adapt to a fast population growth during favourable seasons. Similarly, in the month of February and April, there was a higher density of Brachionus calyciflorus and B. falcatus mostly with eggs in OUSL and Nawala stations. These were the months, which also recorded high temperatures, and lower rain falls during the study period.

Average density values of zooplankton within six sampling stations also have shown a dramatic variation within the study. It reported a high significant positive correlation with DO level $(r=0.72)$. The highest density of zooplankton as well as the highest DO value were recorded from Kotte station, which is associated with Kotte and 
Kolonawa marshes plus the main Diyawanna Oya Lake. In contrast, the lowest density of zooplankton was recorded from Torrington, which also showed lowest average DO value. In some occasions it was noted that there was no fluctuation in that water body. The major reason is that the water column had to be flowed through low elevated area to higher. In such months DO levels were recorded as zero (February, April and May). However, DO values were increased in later months caused by heavy rains, indicating that there is a significant positive correlation between DO level and rain fall. Wickramasinghe, et al. (2012) has observed a similar kind of situation in the study conducted in Kotte and Kolonnawa wetlands. Wickramasinghe has reported a clear differentiation of the density of taxa in flowing and stagnated habitats.

Total alkalinity and hardness of water showed highly significant negative correlation with zooplankton density variation among stations. Torrington, which contained the highest total hardness and total alkalinity values recorded the lowest density of zooplankton. Wallawatta, Kirimandala Mawatha and OUSL stations also obtained highervalues for these environmental characteristics. When considering the species abundance, in stations like Wallawatta and Kirimandala Mawatha, the most commonly occurred species during the period were Philodina sp. and Copepod adult stages. From this study, these species can be considered as tolerant species, which are able to withstand such unfavourable conditions.

The study revealed that conductivity, $\mathrm{pH}$ and $\mathrm{Cl}^{-}$concentrations were negatively correlated with density variation along stations. Wallawatta, which is located close to the outfall to the sea, had the highest value of $\mathrm{Cl}^{-}$concentration and conductivity. This condition is more preferable for planktonic crustaceans like Copepods. As per the results, Wellawatta station was mostly abundant with higher densities of Copepod and some Rotifer sp. such as Philodina sp., Lecane bulla and Lecane ungulata.

\section{Conclusion}

From this study, it was revealed that there was a significant variation of zooplankton species composition, diversity, their abundance and density in the period of February to July 2003 and also among six sampling stations of Diyawanna Oya. Some Rotiferan and Cladoceran taxa like Lacane sp., Philodina sp. and Moina micrura, have shown some indicator properties that can be used to monitor some environmental changes of the canal system. Further studies should be carried out based on this hypothesis for better 
results. Flow rate had shown a very highly significant (VHS) positive correlation with the monthly variation of zooplankton density. There was a highly significant (VHS) positive correlation between DO content and average density variation of zooplankton in six sampling stations. Simultaneously, there was a high significant (HS) negative correlation with alkalinity, hardness and conductivity. The situation may have been changed by now as the canal system had gone through a rapid development process within the last few years by improving the condition of the canals as well as changes in land use in the surrounding. Also a boat service for visitors and daily passengers was established by the government. There after the canal system was occupied with plenty of mechanical boats. As a result, it may have affected by the effluents released out to the water by the boats. The canal system provides livelihoods and food sources for the community which lives around. Also it plays a major role in balancing the environmental health of Colombo metropolitan, which is the capital city of Sri Lanka. Thus, it is vital to pay more attention on proper maintenance of the canal system considering its ecological value as well as the historical and socio-economical values.

\section{Acknowledgements}

The author wishes to express her sincere thank to Dr (Mrs) W. P. N. Chandrananda for her valuable guidance. Also the author highly appreciates the constructive comments and suggestions made by the anonymous reviewers to improve the manuscript.

\section{References}

Battish, S. K. (1992). Fresh Water Zooplankton of India. Oxford \& IBH Publishing Co. Pvt. Ltd. New Delhi.

Branco, C. W. C., Rocha, M. I. A., Pinto, G. F. S., Gômara, G. A. \& De Filippo, R. (2002). Limnological features of Funil Reservoir (R.J., Brazil) and indicator properties ofrotifers and cladocerans of the zooplankton community. Lakes \& Reservoirs: Research and Management, 7, 87-92.

Costa, H. H. \& De Silva, S. S. (1969). Hydrobiology of Colombo (Beira) Lake, I Diurnal variations in Temperature, hydro chemical factors and zooplankton. Bulletin Fisheries Research station, Ceylon, 20(2), 141-149. 
Costa, H. H. \& De Silva, S. S. (1978). The hydrology of Colombo (Beira) Lake, III : Seasonal fluctuations of plankton. Spolia Zey., 32, 35-53.

Dole-Olivier, M. J. et al. (2000). Lotic microcrustacea. Blackwell science Ltd. Freshwater Biology, 44, 63-91.

Fernando, C. H. (1974). A guide to the freshwater fauna of Ceylon. Supplement 4. Bulletin of the freshwater fisheries research station Ceylon, 25(1\&2), 27-81.

Fernando, C. H. \& Rajapaksa, R. (1983). Some remarks on long term and seasonal changes in the zooplankton of Parakrama Samudra. In F. Schiemer (ed), Limnology of Parakrama Samudra, Sri Lanka, Dr W Junk Publishers.

Haberman, J \& Haldna, M. (2014). Indices of zooplankton community as valuable tools in assessing the trophic state and water quality of eutrophic lakes: long term study of Lake Vortsjarv. Journal of Limnology, 73(2), 263-273. doi:http://dx.doi.org/10.4081/jlimnol.2014.828

Kamaladasa, A. I. \& Jayatunga, Y. N. A. (2007). Composition, density and distribution of zooplankton in south west and east lakes of Beira Lake soon after the restoration of South West Lake. Ceylon Journal of Science (Biological Sciences), 36(1), 1-7.

Mendis A. S. \& Fernando, C. H. (1962). A guide to the freshwater fauna of Ceylon. bull. Fisheries research station Ceylon.

Neale, J. W. (1984). The freshwater Ostracoda. In C. H. Fernando (ed), Ecology and biogeography in Sri Lanka, Dr Junk Publishers.

Pedrozo, C. De S. \& Rocha, O. (2005). Zooplankton and water quality of lakes of the Northern Coast of Rio Grande do Sul State, Brazil. Acta Limnol. Bras., 17(4), 445-464.

Rajapaksa, R. \& Fernando, C. H. (1984). Freshwater zooplankton. In C.H. Fernando (ed), Ecology and biogeography in Sri Lanka, Dr Junk Publishers.

Ricci, C. \& Balsamo, M. (2000). The biology and ecology of lotic rotifer and gastrotrichs. Freshwater Biology, 44, 15-28. 
Schöll, K. \& Kiss, A., (2008), Spatial and temporal distribution patterns of zooplankton assemblages (Rotifera, Cladocera, Copepoda) in the

water bodies of the Gemenc floodplain (Duna-Dráva National Park, Hungary). Opuscula Zoologica Budapest, 39, 65-76.

Wetland Site Report - Colombo Flood Detention Areas. (1995).

Wetland Conservation Project, Sri Lanka, Central Environmental Authority.

Wickramasinghe, D. D., Abeygunawardena,R. \& Hettiarachchi, M. (2012). Community structure of zooplankton in two different habitats of Kotte Kolonnawa Wetland, Sri Lanka. International Journal of Environmental Sciences, 3(3), 965-975.

Wignarajah, S. and Amarasiriwardana, P. (1983). Some aspects of the limnology of Bolgada Lake II, Sri Lanka: 1 composition and seasonal fluctuation of zooplankton. Journal of Nal. Sc. Coun. Sri Lanka. 11(2), 255-268.

Received: 21-4-2015 Revised: 31-8-2015 Accepted: 17-9-2015 
